\title{
Decent Work Diagnostics for a Western Balkan Country Stuck in the Neo-liberal Doctrine: The Case of the Republic of Macedonia
}

\author{
DraganTevdovski, University of Sts Cytil and Methodius, Macedonia
}

\begin{abstract}
The paper proposes a strategy of 'decent work diagnostics' for finding out the policy priorities for a country with poor decent work conditions. It is aimed at identifying the most binding constraints on decent work, and setting policies that will target these constraints. The strategy provides a focus on the policies necessary for a country to progressively achieve decent work while at the same time stopping policy makers from using a 'laundry-list' approach, which typifies neo-liberal policies. This methodology is applied to a country from the Western Balkans - the Republic of Macedonia - and it is shown that the country's economic governance strongly resists the implementation of the decent work agenda. The key policy priorities should be oriented towards addressing income inequality and political patronage.
\end{abstract}

\section{KEYWORDS}

Decent work, social dialogue, labor legislation, Republic of Macedonia.

\section{Introduction}

The ILO decent work agenda has been the main policy objective for the international community with regard to labor since 1999. It became part of the UN Millennium Development Goals and there are many regional and country strategies and programs. However, decent work remains inaccessible for many workers from the Western Balkans. These are small open economies from South Eastern Europe which are not yet members of the Eruopean Union (EU). ${ }^{1}$ A recent study by the Decent Work Balkan Network stressed both the very precarious position of workers vis-à-vis employers across different sectors in the region and an inadequate protection of workers. States are unable to guarantee, protect and fulfill socio-economic rights (Solidar, 2012). ${ }^{2}$

The region is characterized by low levels of public expenditure, high labor-market flexibility, the marginalization of trade unions, flat taxation (some countries have a $10 \%$ flat rate of personal income tax and profit tax), economic liberalization (for example, World Bank Doing Business Report), and the destruction of the public health system. In line with this neo-liberal governance agenda, foreign direct investment is the 'holy grail' for policy makers. ${ }^{3}$ Governments usually proclaim that they made many different reforms in the decent work area, but the results are always poor.

This paper proposes a new strategy of 'decent work diagnostics' to identify the policy priorities for a country with unsatisfactory decent work conditions. It is aimed at identifying the most binding constraints on decent work, and setting policies that will target these constraints. This 
strategy is the opposite to the prevailing 'laundry-list' approach whcih implies that any reform is good: the more areas reformed, the better; and the deeper the reform in any area, the better. The idea is taken from the 'growth diagnostics' approach developed by Hausmann, Rodrik and Velascso (2005), which is a methodology for defining a country's economic growth priorities used by the World Bank and the International Monetary Fund (IMF).

The decent work diagnostics adopts a broad overview of the problem and the analytical process of elimination of constraints from the growth diagnostics approach. However, decent work diagnostics introduces completely different elements in the methodology to address different problems. For example, the starting point for growth diagnostics is low levels of private investment, while the starting point for decent work diagnostics is poor decent work conditions. The growth diagnostics asks whether low levels of private investment are due to the high cost of finance or low returns on economic activity, while decent work diagnostics asks whether poor decent work conditions are due to a poor socio-economic context (low labor productivity, bad macroeconomic policy, labor market imbalances), and/or bad institutions (bad social dialogue or bad law enforcement) and/or bad legislation (low level of labor market regulation or inadequacy of laws).

This approach should not be seen as substitute for decent work indicators. Indicators are key tools for measuring progress in achieving decent work. However, indicators have limitations as they are not intended to be diagnostic and they do not tell us a great deal about the underlying processes associated with improving or deteriorating performance (Frey, 2010). The decent work diagnostics provides a focus on the policies necessary for a country to progress towards decent work. From one side this approach may help stop policy makers who use the 'laundry list' approachthat typifies neoliberal policies. From the other side it may raise a consensus in society about the policies necessary for decent work. In addition, due to the relatively short period of awarness about decent work as a concept in the Western Balkans countries (less than five years), this approach should provide increased attention from both policy makers and the public about the most binding constraints on decent work.

The decent work diagnostics is applied to a country from the Western Balkans - the Republic of Macedonia - which has a poor decent work record and where the ILO's approach has not been effective. ${ }^{4}$ The main socio-economic indicators of the country for the year 2012 are: GDP per capita is $65 \%$ lower than the EU average (Eurostat, 2013a); 30,4\% of the population live below the poverty line (SSO, 2012c: 2); 54\% of households that live in poverty have one or more employees (SSOc: 3 ); and the unemployment rate is $31.4 \%$ (SSO, 2012d: 2).

The ILO's approach used in the Decent Work Country Programs is faulty in its logic, because it tries to solve small elements in the wrong framework. For example, the last Decent Work Country Program focuses on the strengthening of the capacity of government institutions and the social partners to improve the governance of the labor market (ILO, 2010). However, the capacity building of the Economic and Social Council, Ministry of Labor and Social Policy and social partners does not provide results in the field of decent work, because the country has broader problems such as political patronage, a lack of an independent judiciary and the strong implementation of neo-liberal policy agendas. So, the capacity building of the trade unions or the better representivity criteria for the social partners are not simple solutions for decent work in Macedonia. Trade unions belong to one of two camps created by the political patronage system and therefore do not protect the interest of the workers, but the political elites they belong to. Decent work conditions have not improved over the decade. In fact socio-economic conditions have only deteriorated. The poverty rate increased from 19\% 1997 to 30,4\% in 2011 (SSO, 1998: 2, 2012c: 2), and the emigration rate of Macedonian citizens reached 26\% of the country's population in 2010 (Bornarova and Janevska, 2012: 5). 
The proposed decent work diagnostics approach offers a broad overview of the approximate determinants of decent work in the Republic of Macedonia, including the socio-economic context, the institutions and the legislative framework, and so explores the constraints on decent work there. The paper is structured as follows: section 2 discusses the methodology, the identification of the constraints on decent work in the Republic of Macedonia is made in section 3, and section 4 concludes and offers policy recommendations.

\section{Methodology: Decent Work Diagnostics}

The main idea for decent work diagnostics is taken from Hausmann et al. (2005). They introduced the growth diagnostics approach for the identification of binding constraints on economic activity, and for setting the policies that will target these constraints. This was in stark contrast to the laundry-list approach which meant simply pursuing whatever reforms seemed feasible, politically practical and enforceable through conditionality. They argue that the laundry-list approach is faulty in its economic logic because of the following considerations. First, the principle of second-best indicates that we cannot be assured that any given reform taken on its own can be guaranteed to be promoting welfare, especially in the presence of multitudes of economic distortions. Second, the best reform is to eliminate the obstacles that stand in its way, which requires not only having complete knowledge of the prevailing distortions but also the capacity to remove them. The idea is simple: rather than utilize a spray-gun approach, in the hope that we will somehow hit the target, the best approach is to focus on the bottlenecks directly.

\section{Figure 1: The Decent Work Diagnostic Decision Tree}

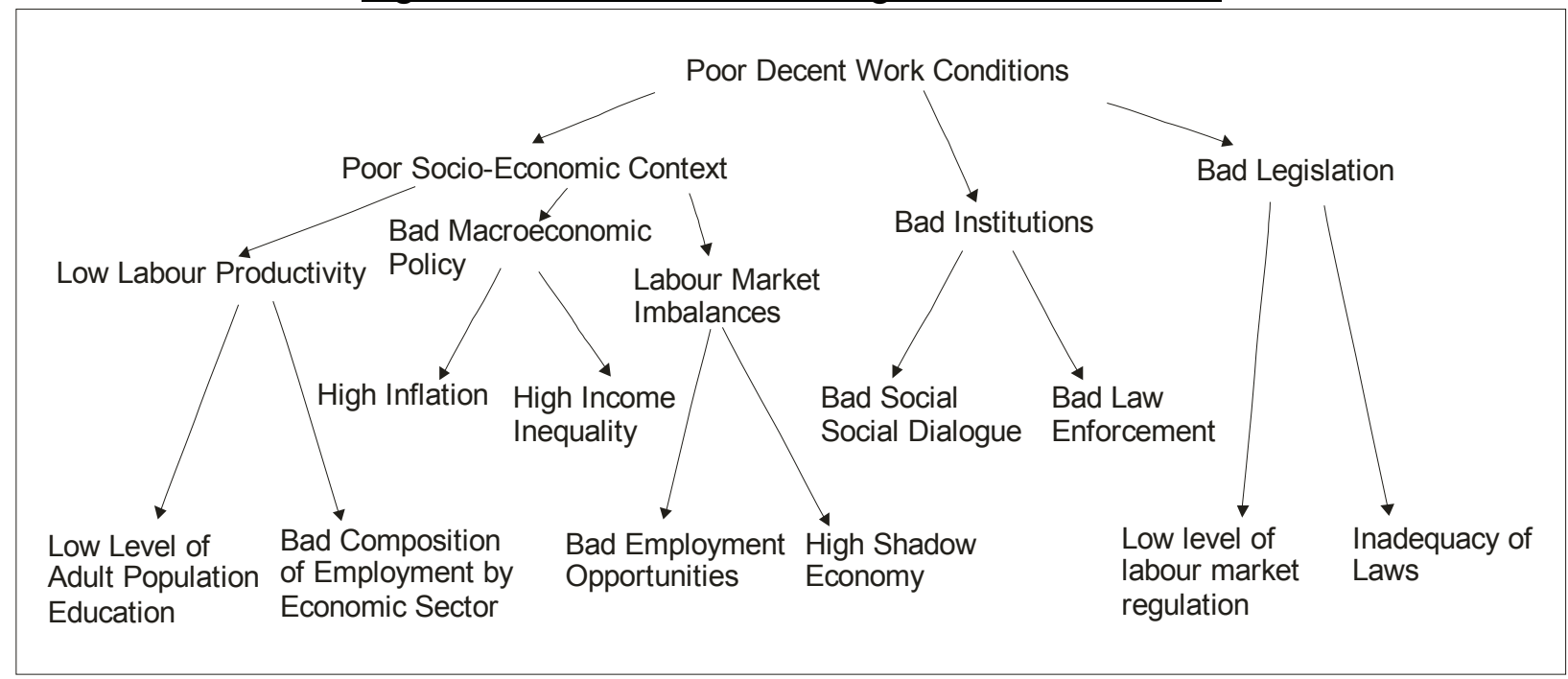

Source: Developed by author.

The decent work diagnostics approach focuses on the most binding constraints of decent work in a country with poor performance. It is based not on specific distortions, but on the proximate determinants of decent work from the policy maker's perspective (labor productivity, shadow economy practices, social dialogue, labor market regulation, etc.). It can be conceptualized as a decision tree (Figure 1). The identification of binding versus nonbinding constraints is made through a process of elimination. Decent work depends on socio-economic context, institutions and 
legislation. The first stage of the decent work diagnostics strategy aims to uncover which of these three factors poses the greatest impediment to achieving decent work. The next stage is to uncover the specific distortions that lie behind the most severe factor. For example, if it is a case of socioeconomic context, it could be due to low labor productivity, bad macroeconomic policy or labor market imbalances. If it is a case of decent work institutions, the problems could be due to bad social dialogue or bad law enforcement. If it is a case of decent work legislation, the problems could be due to low level of labor market regulation or inadequacy of laws. This process of elimination should finish with the identification of one decent work constraint - the binding constraint, the one that deserves most attention from policy makers. This methodolgy is applied to the Republic of Macedonia in the next section.

\section{Identifying the Binding Constraints for Decent Work}

\subsection{Socio-economic Context}

The socio-economic context presents the framework where decent work occurs. In the first part of this subsection, a brief overview of the economic development of the Republic of Macedonia is provided. The second part considers the three aspects of the socio-economic context: labor productivity, macroeconomic policy and the shadow economy.

\subsubsection{Brief overview of the economic development}

Historically, Macedonia's economy was one of the least developed of the former Yugoslavia, and was strongly integrated within the economies of the other republics. In the mid-1980s, the economy of the former Yugoslavia descended into a deep recession that included high international indebtedness, high inflation that turned in hyperinflation, and high unemployment.

The economic development of the Republic of Macedonia in the period after its independence in 1991 can be divided into four periods. The first period is from 1991 to 1995, characterized by a sharp economic decline, hyperinflation, and the presence of two external shocks. Real GDP was reduced by more than $25 \%$ in the period from 1991 to 1994. The fall of real GDP was accompanied by extremely high inflation rates: 1639\% in 1992, 362\% in 1993, and 128\% in 1994 (Petrevski, 2005: 83). At the same time, the United Nations sanctions against the northern neighbor country Serbia (1992-1995), and the trade embargo imposed by Greece (1994-1995), created large-scale isolation of Macedonia's economy. During this period, macroeconomic stabilization was the only priority of the economic policy. A stabilization program was introduced in 1992, characterized by a slowdown in monetary expansion, a tightening of fiscal policy, and the limiting of the credit expansion of state enterprises. As a result of the program's successful implementation, Macedonia achieved a satisfactory level of macroeconomic stability, but the unemployment rate increased dramatically.

The policy of macroeconomic stabilization continued in the next period, from 1996 to 2001. A stable exchange rate and stable price levels were the basic objectives of the economic policy. Throughout this period, real GDP grew, reaching 4.5\% in 2000 (NBRM, 2012: 1). The main sources of growth were industrial production and domestic consumption. Inflation continued to decline, and even deflation of $-0.1 \%$ occurred in 1998. The positive trend in Macedonia's economy ended in 2001, as a result of the internal war conflict. The war conflict reduced the economic activity by

creating significant budgetary spending for security purposes. The crisis affected all the economic sectors. This period was characterized by a significant rise of the income inequality in the country, where the GINI index grew from 28.8 to 38.1 (World Bank Database, 2013). 
The third period is from 2002 to 2008, a period of economic recovery. The economy grew by an average rate of 4.4\% (NBRM, 2012: 1). However, the growth of the economy in this period failed to solve the key problems of the country: high unemployment and poverty.

The period from 2009 till now has been mostly determined by the influence of the Global Crisis. Macedonia's economy started to feel the consequences of the crisis from the end of 2008. The economy entered a recession in 2009, had a low positive growth rate in 2010 and 2011, and again entered recession in 2012. This period was also characterized by a slow-down of the country's integration process in NATO and the EU as the result of the name dispute with Greece, where the right-wing country's government responded with the rise of nationalism and undertook a massive project of building monuments, museums and administrative buildings.

\subsubsection{The three aspects of the socio-economic context}

The three aspects of the socio-economic context are labor productivity, macroeconomic policy and the shadow economy. Labor productivity, measured as GDP per person employed, presents, albeit imperfectly, the overall ability of an economy to generate value from labor inputs. In an economy with low or stagnant labor productivity, policy makers will, at least in the short run, face a less attractive menu of choices vis-à-vis decent work and other economic goals (Anker et al., 2002). The average GDP per person employed (in constant 1990 PPP international dollars) for Western Balkans countries and for EU member countries from South Eastern Europe (Croatia, Bulgaria and Romania) in two periods (2004-2007 and 2008-2011) is presented in Table 1. Macedonian labor productivity is higher than Albanian and Romanian. However, the problem is the stagnant nature of the Macedonian labor productivity in the period 2004-2011. This could lead to the conclusion that the country's labor productivity is not the binding constraint for decent work in the present moment, but that it could be in the near future. Also, it should be noted that a neo-liberal doctrine in economic governance did not achieve its main goal in the observed period.

The second element of the socio-economic context consists of the effects of monetary and fiscal policies on decent work through inflation and income inequality. The presence of high inflation, regardless of its cause, is a signal that the implementation of policies to improve decent work is likely to face an uphill struggle (Anker et al., 2002). High inflation will lower the worker's wage relative to the prices of commodities and services, because wages are often fixed for a specific or indefinite period.

Inflation is not a binding constraint for decent work in Macedonia as monetary policy has obtained a relatively low and stable level of inflation. The exception is only the beginning of transition (the period from 1991 to 1995). The inflation rate in the most recent period is presented in Table 1.

Income inequality is closely connected with decent work. Anker et al. (2002) argue that decent work is unlikely to be viable where the distribution of economic rewards is grossly unequal, and great inequality can be taken as a sign of socio-political resistance to decent work.

Table 1 contains data for the GINI index - the measure of inequality of income distribution for the sample of observed countries in two years - the first and the last year where the data are available in the period 2003-2009. The GINI index significantly increased in Macedonia from 39.0 in 2003 to 43.2 in 2009, as well as in majority of Western Balkans countries, while it decreased only in Serbia and EU member countries Bulgaria and Romania. In addition, it is important to note that Macedonia had highest GINI index in 2009 - the highest income inequality in South Eastern Europe. This fact highlights the great income inequality in the country as the possible binding constraint for decent work. Figure 2 is strong evidence of impoverishment of the central middle class and low middle class in the country (the third $20 \%$ and second $20 \%$ of population). It presents the income distribution in Macedonia in the period 1998-2009. The income share held by the 
highest 20\% of population increased from 36.7\% in 1998 to $48.6 \%$ in 2009 (World Bank Database, 2013). So in 2009 , the income share held by the highest $20 \%$ of population was almost equal to the income share held by the remaining $80 \%$ of the population.

Table 1: Selected Socio-economic Indicators, Republic of Macedonia and Comparator Countries

\begin{tabular}{|c|c|c|c|c|c|c|c|}
\hline \multirow{3}{*}{$\begin{array}{l}\text { Country } \\
\\
\text { Macedonia }\end{array}$} & \multicolumn{2}{|c|}{$\begin{array}{c}\text { GDP per person } \\
\text { employed (constant } 1990 \\
\text { PPP\$) }\end{array}$} & \multirow{3}{*}{$\begin{array}{c}\begin{array}{c}\text { Inflation, } \\
\text { consumer } \\
\text { prices } \\
\text { (annual } \\
\% \text { ) }\end{array} \\
\begin{array}{c}\text { Average } \\
\text { 2008-2012 }\end{array} \\
3.3\end{array}$} & \multirow{2}{*}{\multicolumn{2}{|c|}{$\begin{array}{c}\text { GINI Index } \\
\begin{array}{c}\text { the year is in } \\
\text { brackets }\end{array}\end{array}$}} & \multirow{3}{*}{$\begin{array}{c}\begin{array}{c}\text { Unemployment, } \\
\text { total (\% of total } \\
\text { labor force) }\end{array} \\
\mathbf{2 0 1 1} \\
31.4\end{array}$} & \multirow{3}{*}{$\begin{array}{c}\begin{array}{c}\text { Employment } \\
\text { to } \\
\text { population } \\
\text { ratio, 15+, } \\
\text { total (\%) }\end{array} \\
\begin{array}{c}\text { Average } \\
\text { 2008-2011 }\end{array} \\
37.6\end{array}$} \\
\hline & \multirow{2}{*}{$\begin{array}{c}\begin{array}{c}\text { Average } \\
\mathbf{2 0 0 4 - 2 0 0 7}\end{array} \\
15622 \\
\end{array}$} & \multirow{2}{*}{$\begin{array}{c}\begin{array}{c}\text { Average } \\
\text { 2008-2011 }\end{array} \\
15585\end{array}$} & & & & & \\
\hline & & & & $\begin{array}{c}39 \\
(2003)\end{array}$ & $\begin{array}{c}43.2 \\
(2009)\end{array}$ & & \\
\hline Albania & 11208 & 14697 & 2.9 & $\begin{array}{c}31.1 \\
(2004)\end{array}$ & $\begin{array}{c}34.5 \\
(2008)\end{array}$ & n.a. & 52.3 \\
\hline $\begin{array}{l}\text { Bosnia and } \\
\text { Herzegovina }\end{array}$ & 26618 & 28395 & 3.0 & $\begin{array}{c}35.8 \\
(2004)\end{array}$ & $\begin{array}{c}36.2 \\
(2007)\end{array}$ & 27.6 & 34.1 \\
\hline Montenegro & n.a. & n.a. & 4.0 & $\begin{array}{c}30.1 \\
(2005)\end{array}$ & $\begin{array}{c}30.0 \\
(2008)\end{array}$ & 13.4 & n.a \\
\hline Serbia & n.a. & n.a. & 9.0 & $\begin{array}{c}32.7 \\
(2002)\end{array}$ & $\begin{array}{c}27.8 \\
(2009)\end{array}$ & 19.7 & n.a \\
\hline Croatia & 22972 & 24178 & 3.0 & $\begin{array}{c}29 \\
(2004)\end{array}$ & $\begin{array}{c}33.7 \\
(2009)\end{array}$ & 19.2 & 47.2 \\
\hline Bulgaria & 16253 & 18028 & 4.9 & $\begin{array}{c}29.2 \\
(2003)\end{array}$ & $\begin{array}{c}28.2 \\
(2007)\end{array}$ & 11.2 & 50.0 \\
\hline Romania & 10116 & 11474 & 5.7 & $\begin{array}{c}31.1 \\
(2003)\end{array}$ & $\begin{array}{r}27.4 \\
(2011)\end{array}$ & 7.4 & 52.2 \\
\hline
\end{tabular}

Source: World Bank Database, Indicators: GDP per person employed, Inflation, GINI index, unemployment total, Employment to population ratio total (2013).

There are several important sources of income inequality in the country, and among them more attention will be given to low wages and flat taxation. The median gross hourly earnings in the country was 2.5 euro in 2010, which is almost five times lower than the EU-27 average (Eurostat, 2013b: 1). However, the comparison between wages and the cost of living is the best indicator of whether or not the wages are set at a fair level. Figure 3presents the distribution of employment in the country based on the net wage. The skewness of the distribution is positive - two-thirds of employees receive a wage that is lower than the average in the country (The average net wage in 2011 amounted to 338 euro.) In addition, the Trade Union of Macedonia (2013: 6) estimated that a four-member family needed 504 euro per month to meet the elementary costs of living in 2011 . As shown, 45,9\% of the employees have a wage lower than 228 euro. If both wage earners in a family receive a salary lower than 228 euro (in total 456 euro), their joint income is not sufficient to meet the basic cost of living. This harsh reality is confirmed by the existence of a working poor in the 
country: $54,2 \%$ of households which live under the poverty line have one or more employee (SSO, 2012c: 3).

Figure 2: Income Distribution in Macedonia, 1998-2009

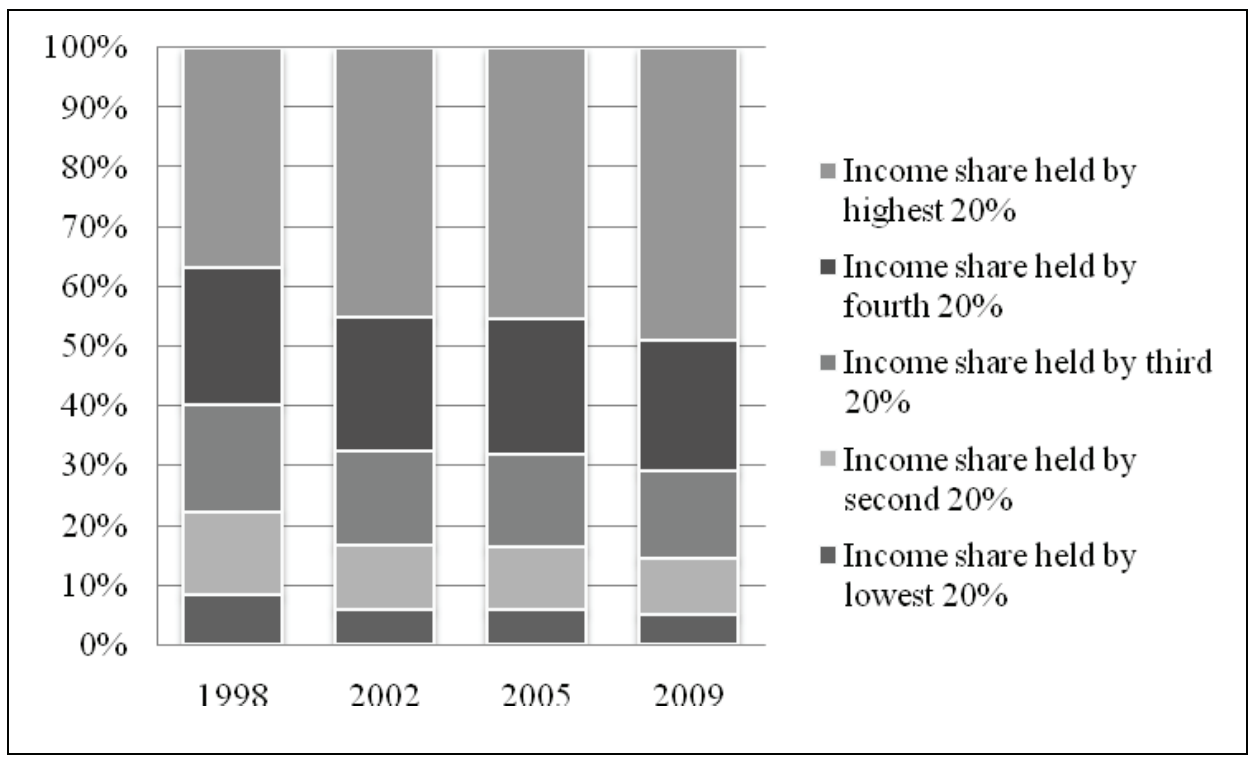

Source: The World Bank Database, Indicator: Income distribution (2013).

The effect of the low wages on income inequality is reinforced by the flat taxation rate. This element of neo-liberal doctrine has found wide adoption in Central and South Eastern European countries in the last two decades. The Republic of Macedonia has had a 10\% flat rate of personal income tax and corporate tax since 2007. This taxation does not contribute to the reduction of income inequality, but strengthens it.

The third element of the socio-economic context is the labor market imbalances. This section should answer the question which part of the labor market - formal or informal - is the bigger constraint for decent work in the country. Employment opportunities in the formal labor market are limited. The average employment to population ratio in the Republic of Macedonia was 37,6\% in 2011 (World Bank Database, 2013) which is low even for Western Balkan standards. Especially worrying is the employment rate of the young population: $51.8 \%$ of the age group 15-24 (SSO, 2012d: 22 ). Also, the employment rate of the women is low and was equal to $30.9 \%$ in 2011 (SSO, 2012d: 20).

The unemployment rate is one of the highest in Europe - 31.4\% in 2011 (SSO, 2012d: 22). The main problem is the long-term dimension of unemployment. Exactly $81,8 \%$ of the unemployed have been out of work for more than one year (World Bank Database, 2013). This group consists predominantly of those who have been unemployed for more than four years $(63,8 \%$ of the total number of unemployed). This has resulted in a diminished human capital stock as people lose their acquired skills and capabilities while waiting to find a new job. These long periods of unemployment indicate that the labor market is suffering from structural constraints (Trpeski, 2011). 
Figure 3: The Distribution of Employment based on the Size of their Net Wage, 2011

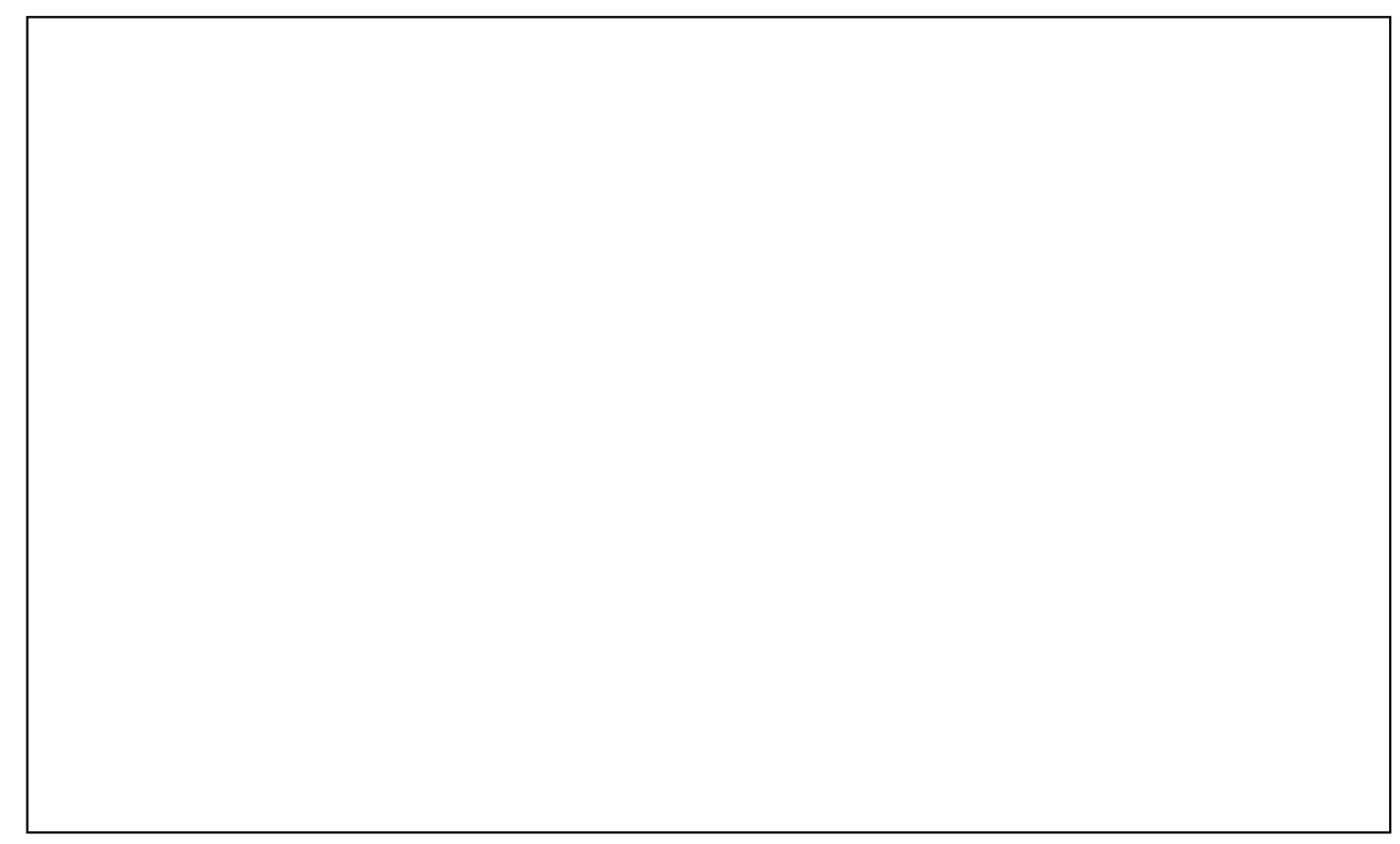


the health and pension insurances. Even while registered with the employment agency, the employers often pay the lowest possible contributions and taxes. Working hours are mostly not fixed, and go up to ten hours a day and include Sundays. An annual vacation is shorter than its legally set duration. Unfortunately, the workers in the shadow economy are forced to accept any type of behavior from their employers since their existence is at stake (Jankulovska, 2002).

It can be concluded that both labor market imbalances are serious constraints for decent work. However, in the present moment, the advantage should be given to the transformation of the existing informal sector into a formal one, because on the one side this will lead to reduction in the abuses of the workers from the shadow economy and from the other side it will decrease the problem of income inequality and poverty.

\subsection{Institutions}

Institutions should underpin decent work. However, in the Republic of Macedonia public institutions are constraints for decent work, because they are abused by the ruling political and economic elites. The existence of the specific system of political patronage allows elites to stay in power despite the widespread unemployment and poverty in the country.

Political patronage is widespread in the South Eastern European region. There is a growing body of literature that deals with the political patronage in other SEE countries - for example, Đukić (2006), Dobrotić (2008), Kajsiu (2010), Upchurch and Marinković (2011), Cvijanović and Redžepagić (2011), and Mavrikos-Adamou (2013). However, it is worth noting that political patronage already existed in the SEE region long before the transition. For example, Pappas (2013), who analyzed Greece - the oldest EU member state from the SEE region (an EU member country from 1981), pointed out political patronage as the main reason for the crisis in Greece: 'Inducements were targeted at specific groups but, since society had been divided into two irreconcilable parts represented by parties regularly alternating in power, all citizens could reasonably expect to gain from patronage once their own party won elections' (Pappas, 2013: 37).

The Macedonian system of political patronage divides society not into two irreconcilable parts, but four parts. In addition to the Greek case, the Macedonian society is divided also on ethnic bases: Macedonian and Albanians. So, there are two Macedonian parts and two Albanian parts in the society, where each part is represented by one major political party.

Overall, there are three types of state-related benefits: (i) real income as wages, pensions and welfare transfers; (ii) a privileged position in terms of market risks, and (iii) protection upon the violations of laws. The first type of state-related benefits is the main tool for creating a voting machinery for the ruling parties. Most common forms of this type are: hiring employees based on party membership, receiving a salary in public administration without having to go to work or at least a having a much greater commitment to political party activities, increase of pensions before elections, welfare transfers for people who do not qualify for it. As a result, the country has an oversized public administration, with low wages, rather than an efficient administration with higher wages. These issues could be found in every European Commission report for Macedonia. I give three examples: (i) The large-scale dismissals of officials following the change of government in 2006 illustrated the politicization of appointments at all levels in the public administration and disrupted its functioning well into 2007. Time and expertise were lost in reorganization and extensive changes of personnel in the public administration (European Commission, 2007); (ii) The increased recruitment of temporary staff, which does not fall under the Law on the Civil Service, undermines

merit-based recruitment. Many of the temporary staff are junior, lack appropriate office space and have no clear job descriptions. (iii) Concerns remain regarding politicization of the public service. There have been reports of replacement of trained professionals with appointees of limited 
experience in several institutions. Also, senior management positions have been filled in the absence of appointment criteria (European Commission, 2010).

The second type of state benefits occurs in different forms, but the two most commonly used ones are agricultural subsidies and the public tenders. The role of subsidies in agriculture is similar to the state benefits from the first type - creating a voting machinery. Thus, the subsidies in agriculture were drastically increased in the period 2006-2012, while the agriculture production remained on the same level as in 2006 and the trade deficit of the country for food products increased more than three-fold. The key 'unwritten' selection criteria for public tenders is the connection with the political elite. The corruption perception index ranks the country in $69^{\text {th }}$ place in the world in 2012, behind such countries as Namibia, Ghana and Lesotho (Transparency International, 2012).

The third type of state-related benefits applies to protection upon the violation of laws: tax evasion, unauthorized construction and protection in the courts. The courts are not independent. According to the Index of judicial independence (published by Economic Freedom of the World [EFN], 2012), the judiciary in the Republic of Macedonia is strongly influenced by members of government, citizens or firms. This index can take a value from 1 to 10 , where 1 means that the judiciary is strongly influenced by members of government, citizens or firms, and a value of 7 or more means that the judiciary is completely independent. Macedonia had an index value of 3.1 in 2010, which is the second-lowest value in the SEE region. Just for comparison, Germany had an index value of 8.9 in 2010 (EFN, 2010).

The trade union movement in the country is therefore drowning in the political patronage system. Trade union membership is falling continuously. Until 1990 union density was nearly 98\% (during socialism all employees were members of a trade union), while in the 2010 union density was about 28\% (Eironline, 2013: 3).

After transition, at the beginning of the 1990s, the trade union movement was characterized by efforts to establish trade union pluralism. In that period two trade unions were established: the Federation of Trade Unions of Macedonia and the Union of Independent and Autonomous Trade Unions. The first was the successor of the trade union from socialism, that inherited widespread organizational network and rather numerous membership. With its 17 branch trade unions, it covered practically all economic and non-economic activities, with approximately 75-80\% of workers organized in trade unions in the country (Hristova, 2007: 231). In 2005 several branch trade unions of Federation of the Trade Unions of Macedonia (education, financial institutions and defense) left headquarters and established separate trade unions. In 2006 and 2009 two new trade unions were established.

Currently the main source of trade union members is the public sector. The coverage in the private sector is very weak. They are present in some of the big privatized companies, while in the newly established firms the employee organization in the trade union is an exception. However, even in the big companies, it is questionable whether trade unions operate completely independently in reference to the company owners (Eironline, 2013).

Figure 4 presents the index of collective wage bargaining in the Western Balkans region. Germany and Slovenia (the most developed countries in the region) are shown as benchmarks. The index values range from 1 to 10, where 1 means that the wages in the country are fixed through the collective bargaining process and 7 that the wage fixing does not depend on this process, but on an individual enterprise. Macedonia has the highest index value in the region, and it may be explained by the lack of a collective bargaining process. 
Figure 4: Index of Collective Wage Bargaining, 2010

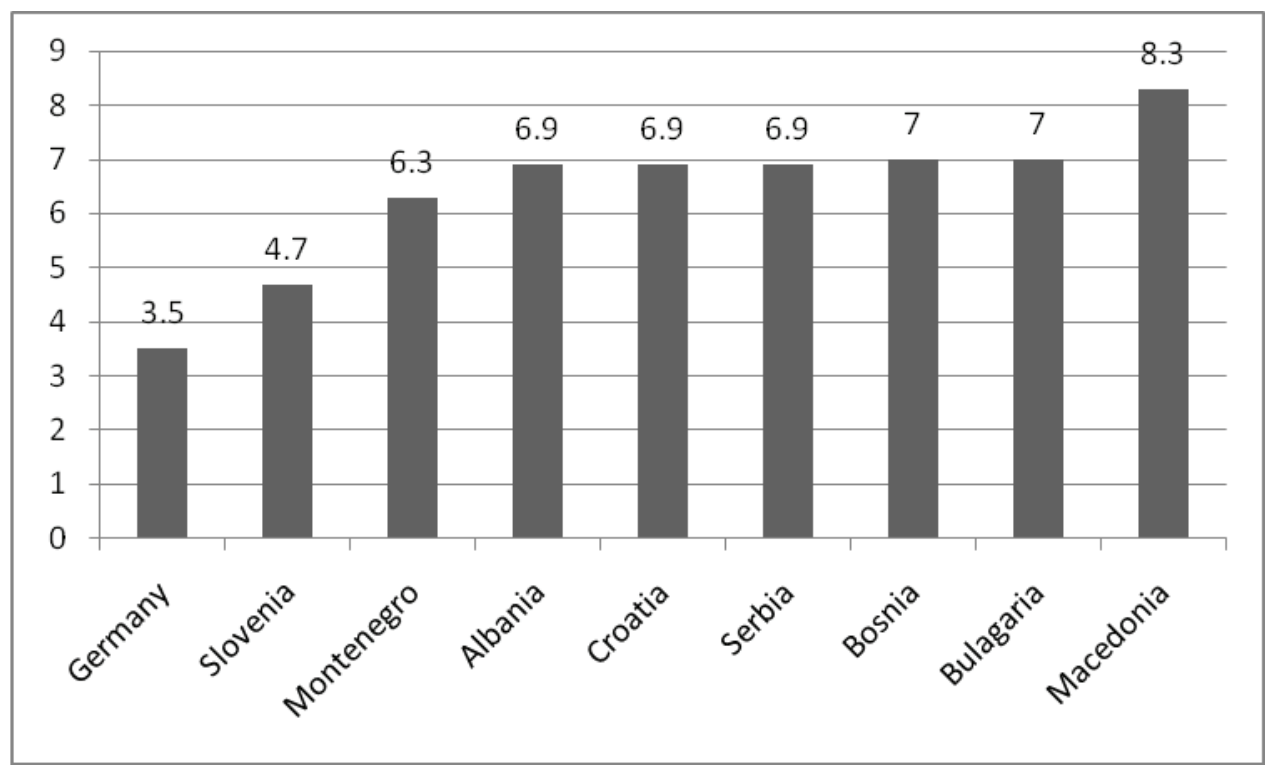

Source: Economic Freedom of the World Data, Index of collective wage bargaining (2012).

The main problem of the trade union movement in the country is their fit in the political patronage system. While the society is divided into camps led by political parties, the trade unions just choose a side. Therefore, they do not represent real workers' rights. There is even informal government control of the trade unions. Hristova (2007) points out their elitist manner of behavior, the disconnection of the leadership from the membership, lack of transparency in the work of the trade union, informal meetings between government and trade union at top level, without including or informing the trade union structures about the course and outcome of the discussions. A decade before, Casale (1999) stressed the dominant role of the state in the Republic of Macedonia.

The same problems of the trade unions are present in the other countries in the SEE region. For example, Careja (2007) found that in the region, while the independence of trade unions is guaranteed and protected by the constitution, often trade unions have developed links with political parties in order to stay in the public eye, to have their demands fulfilled when their allies are in power and, last but not least, to secure the careers of union leaders. Also, Kohl (2009) concludes that in the Western Balkans the trade unions are in no position to meet the challenges on their own, and argued that avenues for social dialogue projects within the structure of European pre-accession support funds need to be explored.

The real social dialogue and the power of the trade unions could not be established before the specific system of political patronage was dismantled and representative democracy built in the society. The first step towards representative democracy should provide free and independent media, judiciary and civil organizations, in order to limit the ability of political parties in power to control everything.

\subsection{Legislation}

The legislation is continuously decreasing labor rights. Figure 5 compares the indices of labor market regulation in 2010 in Western Balkans countries, with Slovenia and Germany as benchmarks. 
The range of index is from 1 to 10 , where 1 means that the labor market is strongly regulated and 7 means that the system is flexible. Macedonia has the second-highest value of the index. The value of 7.8 indicates that the legislation is far more on the side of employers and not sufficiently protecting the workers. It is valuable to note that in 2006 the value of the index in Macedonia was equal to 6.6. Over four years, the regulation of the labor market deteriorated. To compare, the index values for Germany or Slovenia in 2010 were 5.4, and all countries from region had higher values of the index.

Figure 5: Index of Labor Market Regulation, 2010

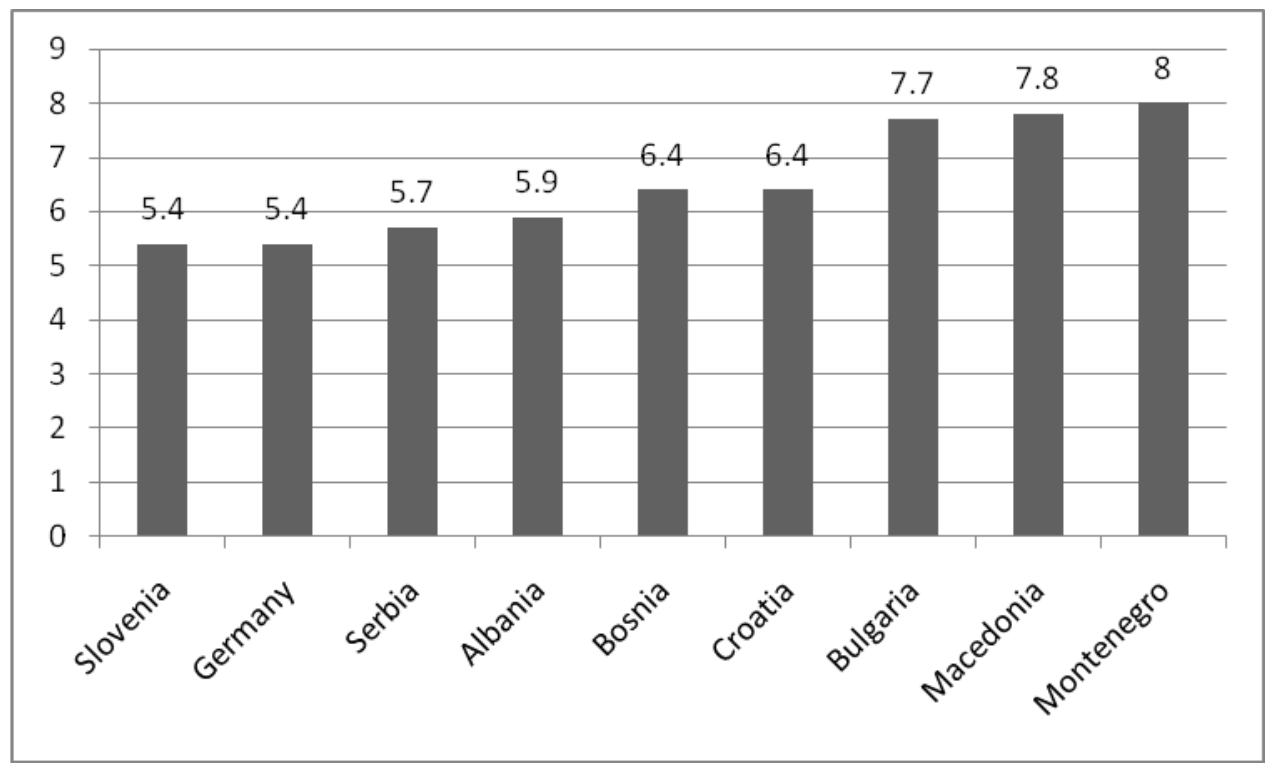

Source: Economic Freedom of the World Database, Index of labor market regulation (2012).

The best example for the trend of deteriorating labor market regulation is the law on employment - lex fundamentalis - governing worker's rights in the country. Since the independence of the country, two laws have been passed - in 1993 and in 2005. The 1993 law on employment was modified eleven times during the twelve-year period. The current law on employment has been through seven modifications. In addition, the Constitutional Court made several decisions to abrogate its provisions. Essentially, each modification has curtailed workers' rights as shown in the last six years by (i) the reduction of the legally allowed annual vacation; (ii) the prolongation of the period of employment for contracts with a definite time; (iii) the cancelation of the priority right to employ persons declared as redundant workers; (iv) the introduction of the possibility to give notice to certain workers due to business reasons and to hire others the very next day for the same position with the same professional background; (v) the reduction of the base used for calculating severance payment; (vi) the abrogation of the imposed ban for employees to work more than one week in a night shift; (vii) allowing employers to ask employees to perform any job duties, and not just those that are appropriate for the workplace; and (viii) the abolition of the right to shortened working hours for disabled persons (Saveski et al., 2010).

Despite the low level of labor market regulation, there are cases of intentional omissions in the legislation made by policy makers. The key example is the Minimum Wage Law, which was 
introduced in 2012, after a struggle of two decades. This law has two weaknesses that prevent the minimum wage from achieving its main objectives. First, the level of the minimum wage does not provide coverage in the elementary costs of living. The minimum wage is set to 130 euro. Two minimum wages, or two parents who receive the minimum wage, could cover only a half of the elementary (not average) goods and services for living of a four-person family in the country. Petrevski (2012) suggests that the optimal level of the minimum wage in the Republic of Macedonia is higher than the current level of the minimum wage - that is, that the minimum wage should be set at 165 euros (48\% of the average salary). This analysis is based on the study by Boeri (2009), where the minimum wage in relation to the average wage is evaluated as a function of several variables: the mode for setting the minimum wage, unemployment benefits, degree of trade openness, as an approximation for the elasticity of labour demand; the degree of progressivity of taxation, income per capita and the rate of inflation. This claim is also supported by the public opinion polls, where $91.6 \%$ of respondents believe that the minimum wage should be higher than 160 euro in order to cover the necessary costs of living (Tevdovski, 2012).

The second weakness of the law is that it contained a three-year compliance period (20122015) for three sectors of the Macedonian economy with the lowest wages (the sectors that most needed the minimum wage). This compliance period basically lowers the declared net amount of minimum wage from 130 euro to 101 euro. These cases only confirmed the neo-liberal intentions of the policy makers in the country, while putting constraints on decent work in the near future.

It can be concluded that labor legislation is an important constraint for decent work. However, it is not a binding constraint in the present moment. The changes of the labor legislation would not lead to the improvement of the decent work conditions in the country in the presence of the abuse of the institutions by the elites. For example, implementation of the legislation practices from the Western countries with more legislative labor protection will not improve the decent work conditions in the country in the presence of a highly dependent judiciary from the political and economic elites. Therefore, the priority should be given to building representative democracy in the country. The solution of this constraint could put the labor legislation as the next possible binding constraint in the near future.

\section{Conclusion and Policy Proposal}

This paper has proposed a decent work diagnostic to identify the key constraints to decent work in a particular economy. It takes into account the socio-economic context, institutions and legislation to enable the tabling of policies that will target these constraints. This methodology has been applied to the Republic of Macedonia, a country from the Western Balkans.

The diagnostic approach identifies three mutually connected binding constraints for decent work in the country: income inequality, the shadow economy and the politicized institutions. The key process in the country is the income and wealth distribution towards the elites. The income inequality has risen dramatically since the beginning of transition, resulting in huge poverty. This process is based on two theoretically opposed mechanisms: neo-liberal doctrine and political patronage. However, in Macedonian reality they have functioned together because the goal of the implemented neo-liberalism is to remove the legislative protection of the workers and to keep the wages on a miserably low level, while political patronage provides elites with the tools for governance. As a consequence, these mechanisms strongly resist the implementation of the decent work agenda and solutions for the shadow economy and precarious workers. In this context, simple solutions such as strengthening the capacity of government institutions and social partners, recommended in the ILO's Decent Work Country Program, cannot bring progress towards decent work. 
Generally, the international organizations initiate and support the neo-liberal agenda in the country. For example, Upchurch (2009) analyzing the International Financial Institutions (IFI) in the post-Communist economies finds that the IFIs' main approach to labor market reform has the following elements: privatization of state-owned enterprises, a program of flexibilization of contacts, regulations on hiring and firing, decentralization of collective bargaining away from former national systems, a reduction in the public service wage bill, a dilution of the minimum wage. In addition, it is important to note that the European Union never put the social dimension high on the country's integration agenda.

The solution of the decent work problem in the Republic of Macedonia should be based on reforms in two directions. The first direction should allow functioning of the representative democracy in the country. It should provide free and independent media, judiciary and civil organizations, in order to limit the power of political parties to control everything. Without them, the elites always will find a way to distort the reform and to direct in their own interest. The second direction should dismantle neo-liberalism and improve decent work conditions. The first step in this direction should be transformation of the shadow economy into the formal one. The next steps could include strengthening the capacities of the trade unions and improvement of labor legislation.

\section{NOTES}

1. The expression Western Balkans is political construction, referring to those parts of South East Europe which are not yet member states of the EU. It includes the successor states and territories of former Yugoslavia (Croatia, Bosnia and Herzegovina, Macedonia, Montenegro, Serbia and Kosovo), minus Slovenia, plus Albania. (Croatia joined the EU in July 2013).

2. In 2011, SOLIDAR (Belgium), the Olof Palme International Center (Sweden), AGENDA Institute (Albania), Center for Democracy Foundation (Serbia), CLARD (Kosovo), the Progress Institute for Social Democracy (Macedonia), STBIH (Bosnia and Herzegovina) and Progetto Sviluppo CGIL (Italy) launched, with the support of the Pan-European Regional Council (PERC) of the International Trade Union Confederation (ITUC), the Decent Work Balkan Network. The aim of the Network is to strengthen joint capacities over the long term and to build effective partnerships stretching across national borders.

3. This process has already happened in the EU new member states (NMS). The EU potential member counties from South Eastern Europe only follow the trend with a significant time lag. In this context, about the NMS, one respected Slovenian economist stated: 'The vacuum created by the collapse of socialism was filled by American advisers promoting a pure "shareholder value" type of capitalism; they were immediately followed by many domestic "Marxists" who quickly turned into "Hayekians". It is also true that many features of the widely admired European social market model no longer existed there when the transition began or when the new member states joined the EU' (Mencinger, 2012).

4. The Republic of Macedonia is the constitutional name of the country. This country is a member of the United Nations (UN) under temporary reference FYR of Macedonia. In addition, it should be noted that the country has had candidate status for the EU from 2006, while the EU integration process was started in 2000.

\section{ACKNOWLEDGEMENTS}

The author acknowledges the comments and suggestions of two anonymous reviewers of this article, and the help of Dr Charles Dannreuther. 


\section{REFERENCES}

Anker, R., Chernyshev, I., Egger P., Mehran, F. and Ritter, J. (2002) Measuring decent work with statistical indicators, Working Paper: 2. Geneva: International Labor Office.

Boeri, T. (2009) Setting the Minimum Wage, IZA Working Paper: 4335. Bern: Institute for the Study of Labor.

Bornarova, S. and Janevska, V. (2012). Social impact of emigration and rural-urban migration in Central and Eastern Europe, European Commission Final Country Report: The Former Yugoslav Republic of Macedonia. Köln: Gesellschaft für Versicherungswissenschaft und -gestaltunge.

Careja, R. (2007). 'Are trade unions effective accounting actors?' SEER SouthEast Europe Review for Labor and Social Affairs, 4: 83-106.

Casale, G. (1999) 'Tripartism and industrial relations in Macedonia', in Casale, G. (ed.) Social dialogue in Central and Eastern Europe. Geneva: International Labor Office.

Cvijanović, V., and Redžepagić, D. (2011). 'From political capitalism to clientelist capitalism: The case of Croatia', Zbornik radova Ekonomskog fakulteta u Rijeci, 29(2): 355-372.

Dobrotić, I. (2008). 'Social care system for defenders from the homeland war', Croatian Journal of Social Policy, 15(1): 57-83.

Đukić, P. (2006). 'The organized world of labor in Serbia today: Between economic reforms and populism', South-East Europe Review of Labor and Social Affairs, 4: 11-30.

Economic Freedom of the World (EFN) (2012) Economic Freedom of the World Data. Available online at http://www.freetheworld.com/ (accessed 19 June 2013).

European Commission (2007). The Former Yugoslav Republic of Macedonia 2007 Progress Report. Brussels: EC.

European Commission (2008). The Former Yugoslav Republic of Macedonia 2008 Progress Report. Brussels: EC.

European Commission (2010). The Former Yugoslav Republic of Macedonia 2010 Progress Report. Brussels: EC.

European Industrial Relations Observatory On-line (Eironline) (2013). Former Yugoslav Republic of Macedonia (FYROM): Industrial relations profile. Available online at http://www.eurofound.europa.eu/eiro/country/macedonia_4.htm (accessed 19 June 2013).

Eurostat (2013a). Eurostat Database: GDP in PPS. Available online at http:/ / epp.eurostat.ec.europa.eu/tgm/table.do?tab=table\&init=1\&plugin=1\&language=en\& pcode $=$ tec00114 (accessed 21 July 2013).

Eurostat (2013b). Wages and Labor Costs. Available online at http://epp.eurostat.ec.europa.eu/statistics_explained/index.php/Wages_and_labour_costs\#F urther_Eurostat_information (accessed 21 July 2013).

Frey, D. (2010) 'A diagnostic methodology for regulating decent work', International Labor Office Conference, Geneva, 9-10 July. 
Fund of Pension and Disabilities Insurance of the Republic of Macedonia (FPDIRM) (2012) Annual report on the work of the Fund of Pension and Disability Insurance of the Republic of Macedonia for 2011. Skopje: FPDIRM.

Hausmann, R., Rodrik, D. and Velascso, A. (2005) 'Growth diagnostics'. Harward University Working Paper. Cambridge MA: Harvard University.

Hristova, L. (2007) 'Trade unions as political actors'. in Mitev, M.G. (ed.) Refreaming social policy: Actors, dimensions and reforms. Skopje: University Sts. Cyril and Methodius and Friedrich Ebert Stiftung.

International Labor Organisation (ILO) (2008) Toolkit for mainstreaming employment and decent work: Country level application. Geneva: International Labor Office.

International Labor Organisation (ILO) (2010) The Former Yugoslav Republic of Macedonia: Decent Work Country Programme 2010-2013. Geneva: International Labor Office.

International Labor Organisation (ILO) (2011) Statistical update on employment in the informal economy, Geneva: International Labor Organization.

International Trade Union Confederation (ITUC) (2011) Annual survey of violations of trade union rights. Brussels: ITUC.

Jankulovska, L. (2002) Working paper in informal economy. Skopje: Federation of Trade Unions in Macedonia.

Kajsiu, B. (2010) 'Down with politics! The crisis of representation in post-Communist Albania', East European Politics and Societis, 24(2): 229-253.

Kohl, H. (2009) 'Social dialogue, workers' rights and freedom of association in the western Balkans: A survey after a first round of empirical research', SEER SouthEast Europe Review for Labor and Social Affairs, 2: 151-173.

Mavrikos-Adamou, T. (2013) 'Rule of law and democratization process: The case of Albania', Democratization, 21(6): 1153-1171.

Mencinger, J. (2012) 'The economics of enlargement', in Swoboda H., Stetter E. and Wiersma J. (eds.) EU enlargement anno 2012: A progressive approach. Brussels: European Union.

National Bank of Republic of Macedonia (NBRM) (2012) Quarterly Bulletin IV 2012. Skopje.

Pappas, T.S. (2013) 'Why Greece failed?’ Journal of Democracy, 24(2): 31-45.

Petrevski, G. (2005) Monetary policy: Theory and Macedonian experience. Skopje: Center for Socioeconomic Development.

Petrevski, M. (2012) Determining the minimum wage. Skopje: CEA.

Saveski, Z., Apasiev, D., Kovachevski , A. and Vasilev, K. (2010) Underestimation of labor: Analysis of labor-legal legislation in the period of transition. Skopje: Lenka.

Schneider, F. (2011) 'Shadow economies all over the world: New estimates for 162 countries from 1999 to 2007', in Schneider, F. (ed.), Handbook on the shadow economy. Cheltenham: Edward Elgar.

Solidar (2012). Making the system work: Ensuring decent work and quality jobs in the Western Balkans. Brussels: Solidar. 
State Statistical Office of the Republic of Macedonia (SSO) (1998) Relative poverty in 1997. Skopje: SSO.

State Statistical Office of the Republic of Macedonia (SSO) (2010) Statistical yearbook of the Republic of Macedonia 2010. Skopje: SSO.

State Statistical Office of the Republic of Macedonia (SSO) (2012a) Active population in the Republic of Macedonia, Results from the poll for labor force, I quarter 2011. Skopje: SSO.

State Statistical Office of the Republic of Macedonia (SSO) (2012b) Employees and their net wages. Skopje: SSO.

State Statistical Office of the Republic of Macedonia (SSO) (2012c) Relative poverty in 2011. Skopje: SSO.

State Statistical Office of the Republic of Macedonia (SSO) (2012d) Labor force survey. Skopje: SSO.

Tevdovski, D. (2012) Monitoring of the implementation of the minimum wage in the Republic of Macedonia. Skopje: Progress Institute.

Tevdovski, D. and Tosevska, K. (2006) 'The main characteristics of the unemployment in Macedonia', Proceedings from the International Scientific Conference - ECOTREND-2006. Targu-Jiu: Constantin Brancusi University.

Trade Union of Macedonia (2012) Syndicate minimal basket. Available online at http:/ / www.ssm.org.mk/index.php?option $=$ com_content\&view $=$ article\&id $=609 \% 3$ Asindikal na-minimalna-kosnica\&catid $=136 \& l a n g=m k$ (Accessed 21 July 2013).

Trade Union of Macedonia (2013) Syndicate minimal basket. Available online at http? / / www.ssm.org.mk/index.php?option $=$ com_content\&view $=$ article $* \mathrm{id}=609 \% 3$ Asindikal na-minimalna-kosnica\&catid=136\&lang $=\mathrm{mk}$ (Accessed 21 July 2013).

Transparency International (2012) Corruption perceptions index 2012. Berlin: Transparency International.

Trpeski, P. (2011) Labor market in the Republic of Macedonia: New Kenzian approach. Bitola: Macedonian Scientific Association.

Upchurch, M. (2009) 'The IFI's and labor reform in post Communist economies', Globalizations, 6(2): 297-316.

Upchurch, M. and Marinković, D. (2011) 'wild capitalism, privatisation and employment relations in Serbia', Employee Relations, 33(4): 316-333.

World Bank (2007) Poverty assessment paper for the Republic of Macedonia. Mimeo.

World Bank (2013) World Bank Database. Available online at http://data.worldbank.org/indicator/ (accessed 21 July 2013).

BIOGRAPHICAL NOTE

DRAGAN TEVDOVSKI is Assistant Professor at the Faculty of Economics, University of Sts. Cyril and Methodius in Skopje, Republic of Macedonia. His primary research interests include labor markets, macroeconomic policy and econometrics. He is coauthor of several books about national 
or regional economies such as: Labor Market Characteristics in Selected Economies and The Macedonian Question: 20 Years Political Struggle into European Integration Structures. In 2012, he won the Annual Global Development Network Research Competition for examination of fiscal and monetary policy interactions in South Eastern European countries with fixed exchange rate regimes. In addition, he writes columns about the Macedonian economy. 